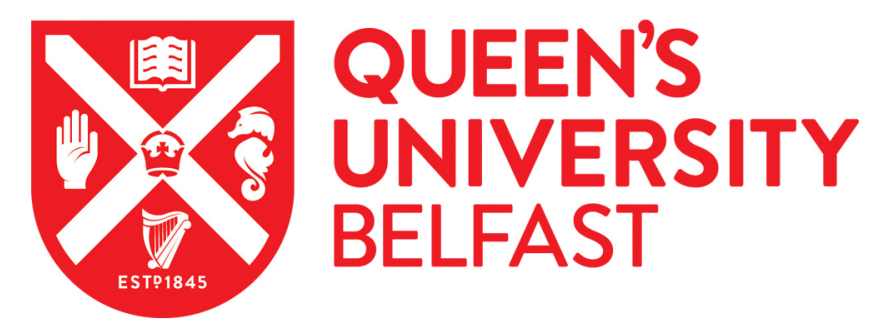

\title{
Investigating the potentially important role of psychological flexibility in adherence to antiretroviral therapy in people living with HIV
}

Fischer, A., Scott, W., Timmins, L., Graham, C. D., \& Harrison, A. M. (2020). Investigating the potentially important role of psychological flexibility in adherence to antiretroviral therapy in people living with HIV. AIDS Care. https://doi.org/10.1080/09540121.2020.1771263

\section{Published in:}

AIDS Care

\section{Document Version:}

Peer reviewed version

Queen's University Belfast - Research Portal:

Link to publication record in Queen's University Belfast Research Portal

Publisher rights

(C) 2020 Informa UK Limited, trading as Taylr \& Francis.

This work is made available online in accordance with the publisher's policies. Please refer to any applicable terms of use of the publisher.

\section{General rights}

Copyright for the publications made accessible via the Queen's University Belfast Research Portal is retained by the author(s) and / or other copyright owners and it is a condition of accessing these publications that users recognise and abide by the legal requirements associated with these rights.

Take down policy

The Research Portal is Queen's institutional repository that provides access to Queen's research output. Every effort has been made to ensure that content in the Research Portal does not infringe any person's rights, or applicable UK laws. If you discover content in the Research Portal that you believe breaches copyright or violates any law, please contact openaccess@qub.ac.uk. 


\section{Investigating the potentially important role of psychological flexibility in adherence to antiretroviral therapy in people living with HIV.}

Anja Harrison ${ }^{1}$, Whitney Scott ${ }^{2}$, Liadh Timmins ${ }^{3}$ and ${ }^{*}$ Christopher D. Graham ${ }^{4}$ Anthony M. Harrison $^{5}$

${ }^{1}$ School of Psychology, University of Central Lancashire

${ }^{2}$ Health Psychology Section, Institute of Psychiatry, Psychology and Neuroscience, King's College London

${ }^{3}$ Cicely Saunders Institute of Palliative Care, Policy \& Rehabilitation, King's College London

${ }^{4}$ School of Psychology, Queen's University Belfast

${ }^{5}$ Leeds and York Partnership National Health Service Foundation Trust, UK

*Joint last authors. Corresponding author information: Anthony Harrison, Leeds and York Partnership National Health Service Foundation Trust, St Mary's Road, Leeds LS7 3JX, UK email: anthony.harrison5@nhs.net

\begin{tabular}{|l|l|}
\hline ORCID & Author \\
\hline https://orcid.org/0000-0002-7872-1292 & Anja Harrison \\
\hline https://orcid.org/0000-0002-2529-9083 & Whitney Scott \\
\hline https://orcid.org/0000-0001-7984-4748 & Liadh Timmins \\
\hline https://orcid.org/0000-0001-8456-9154 & Christopher D Graham \\
\hline https://orcid.org/0000-0001-5651-6004 & Anthony M Harrison \\
\hline
\end{tabular}

Word count: [2999]

Data availability statement: The data that support the findings of this study are openly available in Figshare.com at http://doi.org/10.6084/m9.figshare.9942857.

Funding details: This work was not supported by any funding. 


\section{Abstract:}

Antiretroviral therapy (ART) has significantly improved immune health and survival rates in HIV, but these outcomes rely on near perfect adherence. While many psychosocial factors are related to sub-optimal adherence, effectiveness of associated interventions are modest or inconsistent. The Psychological Flexibility (PF) model underlying Acceptance and Commitment Therapy (ACT) identifies a core set of broadly applicable transdiagnostic processes that may be useful to explain and improve non-adherence. However, PF has not previously been examined in relation to ART adherence. Therefore, this cross-sectional study ( $n=275$ ) explored relationships between PF and intentional/unintentional ART nonadherence in people with HIV. Adults with HIV prescribed ART were recruited online. Participants completed online questionnaires assessing self-reported PF, adherence and emotional and general functioning. Logistic regressions examined whether PF processes were associated with intentional/unintentional non-adherence. Fifty-eight percent of participants were classified as nonadherent according to the Medication Adherence Rating Scale, of which $41.0 \%$ reported intentional and $94.0 \%$ unintentional non-adherence. Correlations between PF and adherence were small. PF did not significantly explain intentional/unintentional non-adherence after controlling for demographic and disease factors. Further clarification of the utility of PF in understanding ART non-adherence is warranted using prospective or experimental designs in conjunction with more objective adherence measures.

\section{Keywords:}


HIV AIDS, adherence, antiretroviral treatment, psychological flexibility, acceptance and commitment therapy (ACT).

\section{Introduction}

The human immunodeficiency virus (HIV) remains a global health concern (UNAIDS, 2014; WHO, 2014). Antiretroviral therapy (ART) slows disease progression and reduces transmission, being widely available in well-resourced countries (Ambrosioni, Calmy, \& Hirschel, 2011; Ingersoll \& Cohen, 2008; Jones, Taylor, Wilkin, \& Hammer, 2007). However, on average people living with HIV (PLWHIV) only take around $70 \%$ of prescribed doses (Malta, Strathdee, Magnanini, \& Bastos, 2008; Simoni et al., 2006).

Individual, treatment and healthcare provider factors contribute to ART non-adherence (García \& Côté, 2003). Common ART side-effects (Raines, Radcliffe, \& Treisman, 2005) do not consistently correlate with non-adherence (Carrieri et al., 2006; Harzke et al., 2004; Molassiotis et al., 2002). Rather, studies show a wide range of psychosocial factors share small to medium associations with ART non-adherence (Catz, Kelly, Bogart, Benotsch, \& McAuliffe, 2000; Gonzalez, Batchelder, Psaros, \& Safren, 2011; Harzke et al., 2004; Ingersoll \& Heckman, 2005; Ironson et al., 2005; Katz et al., 2013; Langebeek et al., 2014; Molassiotis et al., 2002; Ortego et al., 2011; Uthman, Magidson, Safren, \& Nachega, 2014). Most variables included in these studies are guided by Social cognitive models (SCM), which theorise that non-adherence is driven by intentions and beliefs about illness and treatments (Munro, Lewin, Swart, \& Volmink, 2007). Growing evidence suggests that such models lack explanatory power in predicting ART adherence (Brandes \& Mullan, 2014; Horne et al., 2013; Rich, Brandes, Mullan, \& Hagger, 2015). Therefore, unsurprisingly, SCM-informed 
treatment trials aiming to improve adherence also show inconsistent/modest efficacy (Binford, Kahana, \& Altice, 2012; Chaiyachati et al., 2014; Conn, Ruppar, Enriquez, \& Cooper, 2016). It has been theorised that this is because such models underestimate the impact of emotional, behavioural, motivational and wider socio-economic contextual processes on adherence (Michie, Van Stralen, \& West, 2011). Further, it has been argued that SCMs are better placed to explain intentional rather than unintentional non-adherence (i.e. forgetting (Lehane \& McCarthy, 2007)), where adherence depends on conscious costs-benefit expectations/evaluative processes (Edwards, 1954). Although unintentional non-adherence could be due to impaired memory, it might also reflect a socially desirable response, change in mood, disease and treatment burden or access (Lehane, 2007; Molloy, 2014). Therefore, disentangling causes of intentional/unintentional non-adherence may be challenging (Gadkari \& McHorney, 2012).

The Psychological Flexibility model (PF) (Hayes, Strosahl, \& Wilson, 1999) provides an alternative behavioural/psychosocial framework to understand ART non-adherence stemming from philosophical assumptions and basic theory that are distinct from SCMs (Hayes, Barnes-Holmes, \& Roche, 2001; Vilardaga, Hayes, \& Schelin, 2007). Described as a transdiagnostic theory of "normal" human behaviour (McCracken \& Morley, 2014), PF incorporates emotional, motivational and attentional processes that may be lacking in SCM. PF is "the capacity for an individual to persist with, or change, behaviour in a manner that includes conscious and open contact with thoughts and feelings, appreciates what situations afford, and serves one's goals and values" (Scott \& McCracken, 2015, p.91). PF incorporates six interacting sub-processes, including 'mindfulness and acceptance' and 'motivational' 
elements: Acceptance, defusion, self-as-context, present moment awareness, values and committed action (Hayes, Luoma, Bond, Masuda, \& Lillis, 2006).

Psychological inflexibility could explain intentional and unintentional non-adherence to ART. According to Hayes et al.'s (2011) “Open, Aware, and Active/Engaged” facets, PLWHIV may lead a person to behavioural patterns that contribute to non-adherence: Avoid situations, thoughts, feelings or bodily sensations ("Closed") to reduce/eliminate side-effects or anxiety and/or shameful thoughts and feelings related to taking ART.

(ii) Become overly influenced by difficult thoughts and feelings related to ART, unable to take a different perspective ("Unaware"), dwelling on life before their diagnosis and worrying about the future.

(iii)

Fail to identify and pursue valued life directions/goals, and instead persist in unhelpful behaviour ("Inactive/Disengaged"), such as skipping doses and not connecting with how adhering might serve their long-term values/goals (e.g., being independent).

Arguably, experiential avoidance and lack of present moment awareness could occur in and outside of conscious awareness. Therefore, PF does not distinguish between intentional/unintentional non-adherence. PF assumes that effective action, e.g., being adherent, can happen despite difficult thoughts or feelings, low self-efficacy, or contradicting illness/treatment beliefs. HIV studies indicate PF is strongly associated with better self-reported illness management, mental health and quality of life (Chartier et al., 2010; Delaney \& O'Brien, 2012; Landstra, Ciarrochi, Deane, \& Hillman, 2013). 
Acceptance and Commitment Therapy (ACT) is the treatment approach most directly focused on increasing PF (Hayes et al., 2006). Rather than modifying content, frequency or intensity of beliefs or feelings typical of traditional cognitive-behaviour therapy and SCMinformed approaches (Conn et al., 2016; Easthall, Song, \& Bhattacharya, 2013), ACT helps to decrease their literal influence and set current behaviour against a person's values to encourage a more Open, Aware and Engaged stance (Hayes, Levin, Plumb-Vilardaga, Villatte, \& Pistorello, 2013). Consequently, clarity of an individual's informed decisions about treatment could be enhanced. For example, willingness to experience side-effects or negative thoughts about ART, alongside valued-goals around "being healthy", may facilitate adherence.

Evidence supporting ACT for improved general/social functioning has grown in LTCS (Graham, Gouick, Krahé, \& Gillanders, 2016; Hann \& McCracken, 2014). A small, uncontrolled ACT feasibility trial for PLWHIV shows trends towards reductions in viral load and increases in $\mathrm{CD}^{+}$counts post-treatment (Moitra, Herbert, \& Forman, 2011). ACT may improve engagement in medical care for newly diagnosed PLWHIV (Moitra, Chan, \& Stein, 2015) and reduce stigma (Skinta, Lezama, Wells, \& Dilley, 2014). While one study (Berghoff et al., 2018) has identified small relationships between experiential avoidance, nonadherence and strained patient-provider interactions, few have examined other PF subprocesses, intentional/unintentional non-adherence and general functioning. 


\subsection{Study aims and hypotheses}

This study examined the associations between components of PF, self-reported adherence and general functioning. Current evidence suggests an interaction between nonadherence, cognitive impairment, depression and regimen complexity (Hinkin et al., 2002). Therefore, examining PF processes in explaining non-adherence and HIV-related functioning, independent of these variables is important. The following hypotheses were tested:

(i) PF components will be positively associated with adherence, independent of demographic and illness characteristics.

(ii) PF components will be positively associated with general functioning.

\section{Materials and methods}

This international cross-sectional survey (Bristol Online Surveys) recruited $n=283$ PLWHIV 18+ years of age currently prescribed ART (July 2016-2017). The study was approved by Research Ethics Committee King's College London (August 2016: HR-15/16-2496). Informed consent was obtained online. Participants were recruited via online HIV organisations, charities, Facebook and Twitter, identified through NAM AIDSMAP e-atlas (http://www.aidsmap.com/e-atlas). The NAM AIDSMAP e-atlas database includes HIV- 
related charities and organisations globally. Eight cases were excluded (underage $(n=1)$, not prescribed ART $(n=4)$, incomplete survey $(n=3)$.

\subsection{Measures}

\subsubsection{Self-reported medication adherence measure}

The Medication Adherence Report Scale (MARS-5) (Horne, Hankins, \& Jenkins, 2001) measures medication-taking behaviour. The MARS-5 shows good internal reliability and test-retest reliability $(\alpha=0.83)$ in other long-term health conditions (LTCs) (Salt, L, Peden, \& Horne, 2012), despite showing mixed associations with more objective adherence measures (Jónsdóttir et al., 2010; Tommelein, Mehuys, Van Tongelen, Brusselle, \& Boussery, 2014). It has not yet been used with PLWHIV, but unlike other scales distinguishes intentional/unintentional non-adherence (Chesney et al., 2000; Morisky, Green, \& Levine, 1986). Adherence was defined as a score of 25 (100\%). Unintentional non-adherence reflected a subscale-score $<5$ and intentional non-adherence a subscale-score $<20$ (de Vries et al., 2014; Moon, Moss-Morris, Hunter, \& Hughes, 2017).

\subsubsection{Psychological flexibility processes}

Currently, there is no single measure that assessed all PF processes. Therefore, validated self-reported instruments assessed the "Open, Aware, and Active" facets (Hayes et al., 2011). 
The Acceptance and Action Questionnaire (AAQ-II) measures experiential avoidance with good validity/reliability (Bond et al., 2011; Fledderus, Oude Voshaar, ten Klooster, \& Bohlmeijer, 2012). Higher scores reflect greater psychological inflexibility.

The Committed Action Questionnaire (CAQ-8) (McCracken, Chilcot, \& Norton, 2015) has shown promising validity/reliability in chronic pain (McCracken et al., 2015). Higher scores reflect greater committed action.

The Short Form Experiences Questionnaire (SF-EQ) assesses cognitive defusion and selfas context processes with good psychometric properties in people with chronic pain (McCracken, Barker, \& Chilcot, 2014). Higher scores indicate better cognitive defusion/selfas-context.

\subsubsection{Demographic and disease variables}

Demographic and disease factors may be related to a person's level of ART adherence (Carrieri et al., 2006). Age, ethnicity, gender, sexual orientation, education level, current employment, relationship status and time since diagnosis were included. The British Columbia Cognitive Complaints Inventory (BC-CCI) (Iverson \& Lam, 2013) was used to rate perceived common cognitive impairments during the past week (Steinbrink et al., 2013). A preliminarily validation demonstrated good internal consistency. Higher scores indicate worse impairment. 


\subsubsection{Mood}

The Patient Health Questionnaire (PHQ-4) recorded self-reported symptoms of anxiety/depression (Kroenke, Spitzer, Williams, \& Löwe, 2009) and has acceptable psychometric properties (Löwe et al., 2010). Higher scores indicate greater distress.

\subsubsection{Functioning}

The Work and Social Adjustment Scale (WSAS) (Mundt, Marks, Shear, \& Greist, 2002) measured everyday life interference caused by HIV. Higher scores indicate worse illness adjustment. The WSAS demonstrates high internal consistency (Mundt et al., 2002). Established cut-offs were not used because a scaling error occurred.

\subsection{Statistical analyses}

All continuous variables were checked for normality violations (George and Mallery, 2010). The MARS-5 total score (Skewness=-3.24, SE=.17; Kurtosis=13.37, SE=.34) and intentional sub-scale distributions (Skewness=-3.77, SE=.15; Kurtosis=4.29, SE=.04) were both highly negatively skewed. Therefore, established binary cut-offs were used. Pearson's correlations, t-tests and ANOVAs (and non-parametric equivalents: Cramer's $V$ for categorical variables, Pearson biserial correlations $p_{\mathrm{b}}$ for continuous variables) examined associations or differences between the MARS-5 total and intentional/unintentional nonadherence scores with participant demographic, disease and PF predictors. 
Multiple binomial regressions examined relationships between PF sub-processes and intentional/unintentional non-adherence, after controlling for demographic and disease variables. Demographic and disease variables significantly related with non-adherence $(p<.05)$ at the bivariate level were entered in the first step of the models. PF processes were entered in the following step. The proportion of explained variance was assessed using Nagelkerke $R^{2}$ (pseudo $R^{2}$ ). The -2 Log Likelihood statistic (-2LL) assessed model fit. Cases were excluded if $\geq 20.0 \%$ scale item data were missing. Diagnostic checks confirmed the validity of all regression models. Analyses were conducted using SPSS Version 24.

\subsection{A priori power analysis}

No previous studies investigated relationships between PF and self-reported adherence in PLWHIV. Therefore, an a priori power analysis using G*Power version 3.1.9.2. (Faul, Erdfelder, Lang, \& Buchner, 2007) indicated a minimum of 78 participants to detect a medium $R^{2}$ effect size of 0.15 based on studies of other psychosocial adherence correlates in HIV (Langebeek et al., 2014), with $80.0 \%$ power at a two-tailed $\alpha$-level of .05 using a multiple linear regression fixed model, including 15 predictor variables.

\section{Results}

\subsection{Demographics and adherence rates}

Participants $(N=275)$ were mostly white-Caucasian $(74.0 \%)$ and male $(72.0 \%)$ in their late forties, from the UK (46.0\%) and US (52.0\%). The group was divided according to MARS-5 cut-offs and sample characteristics can be found in Table 1 (adherence=25, unintentional 
non-adherence $=<5$ and intentional non-adherence $=<20$ on respective subscales, in line with other LTC samples (de Vries et al., 2014; Moon et al., 2017). Significant differences were found in the cognitive complaints and relationship status variables.

[TABLE 1 HERE]

\subsection{Adherence and general functioning}

General functioning showed a small significant relationship with the dichotomised MARS5 total and intentional nonadherent subscale scores (Table 2). However, it did not correlate with unintentional non-adherence. Medium to large relationships between the WSAS, PF processes, anxiety and depression fell in expected directions.

[TABLE 2 HERE]

\subsection{Intentional/unintentional non-adherence}

Variables associated with intentional non-adherence were gender $(V=.177, p=.01$, $95 \% \mathrm{Cl}=[.06, .29]$, relationship status $(V=.233, p=.022,95 \% \mathrm{Cl}=[.16, .34])$, perceived cognitive complaints $\left(r_{b}=.25, p<.01\right)$, anxiety $\left(r_{b}=.223, p<.01\right)$ and depression $\left(r_{b}=.185, p<.01\right)$. Variables associated with unintentional non-adherence included years since diagnosis $\left(M_{\text {nonadherent }}=16.75, S D_{\text {nonadherent }}=10.65 ; M_{\text {adherent }}=13.60, S D_{\text {adherent }}=12.06, r_{b}=-.144, p=.01\right)$ and perceived cognitive complaints (Table 1). These variables were entered in the first step of the regression models as covariates. 
All biserial relationships between PF processes and the dichotomised adherence outcomes were in expected directions (Table 2). However, intentional non-adherence showed only a small significant association with experiential avoidance and committed action and was unrelated to cognitive defusion or self-as-context. Similarly, unintentional non-adherence was only related to committed action.

The first logistic regression tested PF model components in predicting intentional nonadherence controlling for demographic and disease variables (Table 3). Demographic and disease variables accounted for $19.2 \%$ (Nagelkerke $R^{2}=.192$ ) of the variance in intentional non-adherence, significantly improving the model fit $\left(\chi^{2}(6)=37.66, p<.01\right)$. Specifically, cohabitation (OR=.11, 95\% $\mathrm{Cl}=[.02, .49])$ was associated with decreased odds of intentional non-adherence, and having more cognitive complaints ( $\mathrm{OR}=1.10,95 \% \mathrm{Cl}=[1.02,1.19]$ ) was associated with increased odds of intentional non-adherence. Adding PF processes did not significantly improve the model fit $\left(\Delta \chi^{2}(2)=1.49 \quad(p=.47,2 L L=264.53)\right.$, only explaining a further $0.7 \%$ (Nagelkerke $\Delta R^{2}=.007$ ) of the variance.

\section{[TABLE 3 HERE]}

The second logistic regression tested PF model components in predicting unintentional non-adherence controlling for demographic and disease variables (Table 4). Demographic and disease variables accounted for $11.9 \%$ (Nagelkerke $R^{2}=.119$ ) of the variance in unintentional non-adherence, significantly improving the model fit $\left(\chi^{2}(7)=25.39, p<.01\right)$. Being married or civil partnered $(\mathrm{OR}=.45,95 \% \mathrm{Cl}=[.23, .86])$ or widowed $(\mathrm{OR}=.16$, $95 \% \mathrm{Cl}=[.04, .59])$ was associated with decreased odds of unintentional non-adherence. 
Conversely, more years since diagnosis (OR=1.02., 95\% $\mathrm{Cl}=[1.00,1.04])$ and more cognitive complaints $(\mathrm{OR}=1.08,95 \% \mathrm{Cl}=[1.02,1.14])$ were associated with increased odds of unintentional non-adherence. Adding committed action did not significantly improve the model fit $\left(\Delta \chi^{2}(1)=693 p=.40,2 \mathrm{LL}=349.53\right.$, Nagelkerke $\left.\Delta R^{2}=.003\right)$.

\section{[TABLE 4 HERE]}

\section{Discussion}

This is the first published study investigating PF processes in conjunction with intentional/unintentional ART non-adherence and general functioning in PLWHIV. Overall, small, significant bivariate relationships indicated greater PF was associated with better adherence. Yet, PF was not significantly associated with self-reported intentional/unintentional non-adherence after controlling for demographic and disease variables, with little difference between non-adherence-subtypes. The most potent predictors of non-adherence were being single, more time since diagnosis and perceived cognitive problems. The former emphasises the importance of contextual factors, while the latter is consistent with evidence showing poorer cognitive performance is associated with non-adherence (Lovejoy \& Suhr, 2009). Similar to other psychological variables in LTCS (Kardas, Lewek, \& Matyjaszczyk, 2013), these findings suggest PF processes have some, albeit limited, explanatory power in understanding ART non-adherence in PLWHIV. HIVspecific psychological processes appear to be bigger drivers of non-adherence than general psychological factors (Catz et al., 2000; Fekete, Williams, \& Skinta, 2018; Rachlis, Mills, \& Cole, 2011). 
There are several possible reasons why PF processes showed small correlations with selfreported non-adherence. First, self-reporting biases may have occurred and/or cut-offs used might not capture variability in PF, emotional or general functioning. Conversely, PF measures could be too 'broad-brush' to predict non-adherence, such that adherence behaviours might reflect only one among many other valued-actions. Constructing a nonadherence-specific PF scale that is sufficiently sensitive but does not inadvertently overlap with adherence instruments remains challenging. Future research should use additional objective ART adherence measures.

Second, it is plausible that participants provided an average rating over a self-selected timeframe on MARS-5 and PF scales, which is unspecified on both instruments. Arguably, retrospective bias can also arise (Moskowitz \& Young, 2006). Using an adherence measure validated in PLWHIV with established cut-offs and a specific timeframe may help (e.g., (Chesney et al., 2000). Whilst further validation of the MARS-5 and its intentional/unintentional non-adherence cut-offs in PLWHIV is warranted, our findings indicate PF does not distinguish between them. One alternative might be to use objective momentary assessments of adherence, PF and general functioning within ecological momentary assessment (EMA) studies (Moitra \& Gaudiano, 2016). This approach captures dynamic changes over time and across contexts. EMA methods also examine withinindividual and group-level relationships between variables in conjunction with relevant events or changes in routine (Hektner, Schmidt, \& Csikszentmihalyi, 2007).

The medium to large relationships observed between PF processes, general and emotional functioning are consistent with other LTC studies (Graham et al., 2016; Kashdan 
\& Rottenberg, 2010; Veehof, Trompetter, Bohlmeijer, \& Schreurs, 2016), supporting the transdiagnostic applicability of PF. ACT may help PLWHIV manage distress since approximately $30.0 \%$ receiving ART report anxiety/depression (Lowther, Selman, Harding, \& Higginson, 2014). Depression is a consistent predictor of ART non-adherence (Gonzalez et al., 2011) but this study found small/negligible relationships between self-reported nonadherence, emotional and general functioning. This contrasts with the expectation that less than perfect adherence triggers low mood and reduces functioning or vice-a-versa. Perhaps when ART adherence is more strongly associated with mood and/or functioning, PF processes may play a stronger role in predicting adherence. There is an implicit assumption that non-adherence-related symptom deterioration equates to reduced engagement in valued activities. However, ACT trials in LTCS show reductions in distress, indicating that people can live valued lives despite the presence of difficult symptoms and prognoses (Graham et al., 2016), which may of course include PWLHIV making a valued-choice to not adhere.

\subsection{Limitations}

Causation cannot be inferred due to the cross-sectional design of the study. Additionally, the MARS-5 is not validated in PLWHIV and including objective biomarkers to assess adherence would have been preferable. Online recruitment may have introduced selfselection bias. Indeed, over $70.0 \%$ of the sample was white and male, which is unrepresentative of PLWH. Furthermore, the sample was split between English-speaking UK and US residents. The generalisability of findings to non-Western countries requires investigation. Other psychosocial factors that also play a significant role in adherence for 
PLWHIV, such as economic circumstances, stigma and lack of social support, were not assessed thus limiting generalisability of findings. Finally, the study did not distinguish between disease severity, PLWHIV and those with AIDS or different treatment regimens.

\subsection{Treatment Implications and Conclusions}

This evaluation did not provide evidence that the PF model is more suitable than existing SCMs in explaining non-adherence to ART. Therefore, ACT, which is the treatment approach most directly linked to increasing PF, may not be more suited to addressing non-adherence than existing behaviour change approaches informed by SCMs. However, this is the first evaluation and further research with sensitive HIV-specific proximal measurements and longitudinal methods may provide more clarity.

Currently, studies focusing specifically on ART adherence are mostly small, uncontrolled and have not measured PF processes. Assessment of contextual factors alongside key therapeutic mechanisms in larger trials after EMA investigations will further clarify the utility of the PF model. Moderation analyses will help determine who may benefit and identify at risk groups.

\section{Acknowledgements:}

We would like to express our thanks to Professor Lance McCracken for his invaluable feedback on the project and UKCAB patient and public involvement members for informative feedback on the questionnaire. 


\section{Disclosure:}

No potential conflict of interest was reported by the authors.

\section{References}

Ambrosioni, J., Calmy, A., \& Hirschel, B. (2011). HIV treatment for prevention. Journal of the International AIDS Society, 14(1), 28. doi: 10.1126/science.334.6063.1628

Berghoff, C. R., Gratz, K. L., Portz, K. J., Pinkston, M., Naifeh, J. A., Evans, S. D., . . Tull, M. T. (2018). The Role of Emotional Avoidance, the Patient-Provider Relationship, and Other Social Support in ART Adherence for HIV+ Individuals. AIDS and Behavior, 22(3), 929-938. doi: 10.1007/s10461-017-1745-2

Binford, M. C., Kahana, S. Y., \& Altice, F. L. (2012). A systematic review of antiretroviral adherence interventions for HIV-infected people who use drugs. Current HIV/AIDS Reports, 9(4), 287-312. doi: 10.1007/s11904-012-0134-8

Bond, F. W., Hayes, S. C., Baer, R. A., Carpenter, K. M., Guenole, N., Orcutt, H. K., . . Zettle, R. D. (2011). Preliminary psychometric properties of the Acceptance and Action Questionnaire-II: A revised measure of psychological inflexibility and experiential avoidance. Behavior Therapy, 42(4), 676-688. doi: 10.1016/j.beth.2011.03.007 
Brandes, K., \& Mullan, B. (2014). Can the common-sense model predict adherence in chronically ill patients? A meta-analysis. Health psychology review, 8(2), 129-153. doi: $10.1080 / 17437199.2013 .820986$

Carrieri, M. P., Leport, C., Protopopescu, C., Cassuto, J.-P., Bouvet, E., Peyramond, D., . . . Spire, B. (2006). Factors associated with nonadherence to highly active antiretroviral therapy: a 5-year follow-up analysis with correction for the bias induced by missing data in the treatment maintenance phase. JAIDS Journal of Acquired Immune Deficiency Syndromes, 41(4), 477-485. doi: 10.1097/01.qai.0000186364.27587.0e

Catz, S. L., Kelly, J. A., Bogart, L. M., Benotsch, E. G., \& McAuliffe, T. L. (2000). Patterns, correlates, and barriers to medication adherence among persons prescribed new treatments for HIV disease. Health Psychology, 19(2), 124. doi: 10.1037/02786133.19.2.124

Chaiyachati, K. H., Ogbuoji, O., Price, M., Suthar, A. B., Negussie, E. K., \& Bärnighausen, T. (2014). Interventions to improve adherence to antiretroviral therapy: a rapid systematic review. Aids, 28, S187-S204. doi: 10.1097/QAD.0000000000000252

Chartier, M., Vinatieri, T., DeLonga, K., McGlynn, L. M., Gore-Felton, C., \& Koopman, C. (2010). A pilot study investigating the effects of trauma, experiential avoidance, and disease management in HIV-positive MSM using methamphetamine. Journal of the International Association of Physicians in AIDS Care, 9(2), 78-81. doi:

$10.1177 / 1545109709360065$

Chesney, M. A., Ickovics, J., Chambers, D., Gifford, A., Neidig, J., Zwickl, B., . . (2000). Selfreported adherence to antiretroviral medications among participants in HIV clinical trials: the AACTG adherence instruments. AIDS Care, 12(3), 255-266. doi: $10.1080 / 09540120050042891$ 
Conn, V. S., Ruppar, T. M., Enriquez, M., \& Cooper, P. (2016). Medication adherence interventions that target subjects with adherence problems: systematic review and meta-analysis. Research in Social and Administrative Pharmacy, 12(2), 218-246. doi: 10.1016/j.sapharm.2015.06.001

de Vries, S. T., Keers, J. C., Visser, R., de Zeeuw, D., Haaijer-Ruskamp, F. M., Voorham, J., \& Denig, P. (2014). Medication beliefs, treatment complexity, and non-adherence to different drug classes in patients with type 2 diabetes. Journal of Psychosomatic Research, 76(2), 134-138. doi: 10.1016/j.jpsychores.2013.11.003

Delaney, E., \& O'Brien, W. H. (2012). The association between acceptance and mental health while living with HIV. Social Work in Mental Health, 10(3), 253-266. doi: $10.1080 / 15332985.2011 .649107$

Easthall, C., Song, F., \& Bhattacharya, D. (2013). A meta-analysis of cognitive-based behaviour change techniques as interventions to improve medication adherence. BMJ Open, 3(8), e002749.

Edwards, W. (1954). The theory of decision making. Psychological bulletin, 51(4), 380.

Faul, F., Erdfelder, E., Lang, A.-G., \& Buchner, A. (2007). G* Power 3: A flexible statistical power analysis program for the social, behavioral, and biomedical sciences. Behavior Research Methods, 39(2), 175-191. doi: 10.3758/bf03193146

Fekete, E. M., Williams, S. L., \& Skinta, M. D. (2018). Internalised HIV-stigma, loneliness, depressive symptoms and sleep quality in people living with HIV. Psychology \& Health, 33(3), 398-415. doi: 10.1080/08870446.2017.1357816

Fledderus, M., Oude Voshaar, M. A., ten Klooster, P. M., \& Bohlmeijer, E. T. (2012). Further evaluation of the psychometric properties of the Acceptance and Action Questionnaire-II. Psychological Assessment, 24(4), 925. doi: 10.1037/a0028200 
Gadkari, A. S., \& McHorney, C. A. (2012). Unintentional non-adherence to chronic prescription medications: how unintentional is it really? BMC Health Services Research, 12(1), 98.

García, P. R., \& Côté, J. K. (2003). Factors affecting adherence to antiretroviral therapy in people living with HIV/AIDS. Journal of the Association of Nurses in AIDS Care, 14(4), 37-45. doi: $10.1177 / 1055329003252424$

Gonzalez, J. S., Batchelder, A. W., Psaros, C., \& Safren, S. A. (2011). Depression and HIV/AIDS treatment nonadherence: a review and meta-analysis. Journal of Acquired Immune Deficiency Syndromes (1999), 58(2). doi: 10.1097/QAI.0b013e31822d490a

Graham, C. D., Gouick, J., Krahé, C., \& Gillanders, D. (2016). A systematic review of the use of Acceptance and Commitment Therapy (ACT) in chronic disease and long-term conditions. Clinical Psychology Review, 46, 46-58. doi: 10.1016/j.cpr.2016.04.009

Hann, K. E., \& McCracken, L. M. (2014). A systematic review of randomized controlled trials of Acceptance and Commitment Therapy for adults with chronic pain: Outcome domains, design quality, and efficacy. Journal of Contextual Behavioral Science, 3(4), 217-227. doi: 10.1016/j.jcbs.2014.10.001

Harzke, A., Williams, M., Nilsson-Schönnesson, L., Ross, M., Timpson, S., \& Keel, K. (2004). Psychosocial factors associated with adherence to antiretroviral medications in a sample of HIV-positive African American drug users. AIDS Care, 16(4), 458-470. doi: $10.1080 / 09540120410001683394$

Hayes, S. C., Barnes-Holmes, D., \& Roche, B. (2001). Relational frame theory: A postSkinnerian account of human language and cognition: London: Kluwer.

Hayes, S. C., Levin, M. E., Plumb-Vilardaga, J., Villatte, J. L., \& Pistorello, J. (2013). Acceptance and commitment therapy and contextual behavioral science: Examining 
the progress of a distinctive model of behavioral and cognitive therapy. Behavior Therapy, 44(2), 180-198. doi: 10.1016/j.beth.2009.08.002

Hayes, S. C., Luoma, J. B., Bond, F. W., Masuda, A., \& Lillis, J. (2006). Acceptance and commitment therapy: Model, processes and outcomes. Behaviour Research and Therapy, 44(1), 1-25. doi: 10.1016/j.brat.2005.06.006

Hayes, S. C., Strosahl, K. D., \& Wilson, K. G. (1999). Acceptance and commitment therapy: An experiential approach to behavior change: New York: Guilford.

Hayes, S. C., Villatte, M., Levin, M., \& Hildebrandt, M. (2011). Open, aware, and active: Contextual approaches as an emerging trend in the behavioral and cognitive therapies. Annual Review of Clinical Psychology, 7, 141-168. doi: 10.1146/annurevclinpsy-032210-104449

Hektner, J. M., Schmidt, J. A., \& Csikszentmihalyi, M. (2007). Experience sampling method: Measuring the quality of everyday life. London: Sage.

Hinkin, C., Castellon, S., Durvasula, R., Hardy, D., Lam, M., Mason, K., ... Stefaniak, M. (2002). Medication adherence among HIV+ adults effects of cognitive dysfunction and regimen complexity. Neurology, 59(12), 1944-1950. doi:

10.1212/01.WNL.0000038347.48137.67

Horne, R., Chapman, S. C., Parham, R., Freemantle, N., Forbes, A., \& Cooper, V. (2013). Understanding patients' adherence-related beliefs about medicines prescribed for long-term conditions: a meta-analytic review of the Necessity-Concerns Framework. PloS One, 8(12), e80633. doi: 10.1371/journal.pone.0080633

Horne, R., Hankins, M., \& Jenkins, R. (2001). The Satisfaction with Information about Medicines Scale (SIMS): a new measurement tool for audit and research. Quality in Health Care, 10(3), 135-140. doi: 10.1136/qhc.0100135.. 
Ingersoll, K. S., \& Cohen, J. (2008). The impact of medication regimen factors on adherence to chronic treatment: a review of literature. Journal of Behavioral Medicine, 31(3), 213-224. doi: doi: 10.1007/s10865-007-9147-y

Ingersoll, K. S., \& Heckman, C. J. (2005). Patient-Clinician Relationships and Treatment System Effects on HIV Medication Adherence. AIDS and Behavior, 9(1), 89-101. doi: $10.1007 / \mathrm{s} 10461-005-1684-1$

Ironson, G., O'cleirigh, C., Fletcher, M. A., Laurenceau, J. P., Balbin, E., Klimas, N., . . Solomon, G. (2005). Psychosocial factors predict CD4 and viral load change in men and women with human immunodeficiency virus in the era of highly active antiretroviral treatment. Psychosomatic Medicine, 67(6), 1013. doi: 10.1097/01.psy.0000188569.58998.c8

Iverson, G. L., \& Lam, R. W. (2013). Rapid screening for perceived cognitive impairment in major depressive disorder. Annals of Clinical Psychiatry, 25(2), 135-140.

Jones, J., Taylor, B., Wilkin, T. J., \& Hammer, S. M. (2007). Advances in antiretroviral therapy. Topics in HIV Medicine, 15(2), 48.

Jónsdóttir, H., Opjordsmoen, S., Birkenaes, A. B., Engh, J. A., Ringen, P. A., Vaskinn, A., . . Andreassen, O. A. (2010). Medication adherence in outpatients with severe mental disorders: relation between self-reports and serum level. Journal of Clinical Psychopharmacology, 30(2), 169-175. doi: 10.1097/JCP.0b013e3181d2191e Kardas, P., Lewek, P., \& Matyjaszczyk, M. (2013). Determinants of patient adherence: a review of systematic reviews. Frontiers in Pharmacology, 4, 91. doi: 10.3389/fphar.2013.00091 
Kashdan, T. B., \& Rottenberg, J. (2010). Psychological flexibility as a fundamental aspect of health. Clinical Psychology Review, 30(7), 865-878. doi: https://doi.org/10.1016/j.cpr.2010.03.001

Katz, I. T., Ryu, A. E., Onuegbu, A. G., Psaros, C., Weiser, S. D., Bangsberg, D. R., \& Tsai, A. C. (2013). Impact of HIV-related stigma on treatment adherence: systematic review and meta-synthesis. Journal of the International AIDS Society, 16, 1-25. doi:

10.7448/IAS.16.3.18640

Kroenke, K., Spitzer, R. L., Williams, J. B., \& Löwe, B. (2009). An ultra-brief screening scale for anxiety and depression: the PHQ-4. Psychosomatics, 50(6), 613-621. doi: $10.1016 / \mathrm{S0033-3182(09)70864-3}$

Landstra, J. M., Ciarrochi, J., Deane, F. P., \& Hillman, R. J. (2013). Identifying and describing feelings and psychological flexibility predict mental health in men with HIV. British Journal of Health Psychology, 18(4), 844-857. doi: 10.1111/bjhp.12026

Langebeek, N., Gisolf, E. H., Reiss, P., Vervoort, S. C., Hafsteinsdóttir, T. B., Richter, C., . . Nieuwkerk, P. T. (2014). Predictors and correlates of adherence to combination antiretroviral therapy (ART) for chronic HIV infection: a meta-analysis. BMC Medicine, 12(1), 142. doi: 10.1186/s12916-014-0142-1

Lehane, E., \& McCarthy, G. (2007). Intentional and unintentional medication nonadherence: a comprehensive framework for clinical research and practice? A discussion paper. International Journal of Nursing Studies, 44(8), 1468-1477. doi: 10.1016/j.ijnurstu.2006.07.010

Lovejoy, T. I., \& Suhr, J. A. (2009). The relationship between neuropsychological functioning and HAART adherence in HIV-positive adults: a systematic review. Journal of Behavioral Medicine, 32(5), 389-405. doi: 10.1007/s10865-009-9212-9 
Löwe, B., Wahl, I., Rose, M., Spitzer, C., Glaesmer, H., Wingenfeld, K., . . Brähler, E. (2010). A 4-item measure of depression and anxiety: validation and standardization of the Patient Health Questionnaire-4 (PHQ-4) in the general population. Journal of Affective Disorders, 122(1-2), 86-95. doi: 10.1016/j.jad.2009.06.019

Lowther, K., Selman, L., Harding, R., \& Higginson, I. J. (2014). Experience of persistent psychological symptoms and perceived stigma among people with HIV on antiretroviral therapy (ART): a systematic review. International Journal of Nursing Studies, 51(8), 1171-1189. doi: 10.1016/j.ijnurstu.2014.01.015

Malta, M., Strathdee, S. A., Magnanini, M. M. F., \& Bastos, F. I. (2008). Adherence to antiretroviral therapy for human immunodeficiency virus/acquired immune deficiency syndrome among drug users: a systematic review. Addiction, 103(8), 1242-1257. doi: doi:10.1111/j.1360-0443.2008.02269.x

McCracken, L., Chilcot, J., \& Norton, S. (2015). Further development in the assessment of psychological flexibility: A shortened Committed Action Questionnaire (CAQ-8). European Journal of Pain, 19(5), 677-685. doi: 10.1002/ejp.589

McCracken, L. M., Barker, E., \& Chilcot, J. (2014). Decentering, rumination, cognitive defusion, and psychological flexibility in people with chronic pain. Journal of Behavioral Medicine, 37(6), 1215-1225. doi: 10.1007/s10865-014-9570-9

McCracken, L. M., \& Morley, S. (2014). The psychological flexibility model: a basis for integration and progress in psychological approaches to chronic pain management. The Journal of Pain, 15(3), 221-234. doi: 10.1016/j.jpain.2013.10.014

Moitra, E., Chan, P. A., \& Stein, M. D. (2015). Open Trial of an Acceptance-Based Behavior Therapy Intervention to Engage Newly Diagnosed HIV Patients in Care Rationale and Evidence of Feasibility and Acceptability. Behavior Modification, 0145445515590977. 
Moitra, E., \& Gaudiano, B. A. (2016). A psychological flexibility model of medication adherence in psychotic-spectrum disorders. Journal of Contextual Behavioral Science, 5(4), 252-257. doi: 10.1016/j.jcbs.2016.10.003

Moitra, E., Herbert, J. D., \& Forman, E. M. (2011). Acceptance-based behavior therapy to promote HIV medication adherence. AIDS Care, 23(12), 1660-1667. doi: 10.1080/09540121.2011.579945

Molassiotis, A., Nahas-Lopez, V., Chung, W. R., Lam, S. C., Li, C. P., \& Lau, T. J. (2002). Factors associated with adherence to antiretroviral medication in HIV-infected patients. International journal of STD \& AIDS, 13(5), 301-310. doi:

\section{$10.1258 / 0956462021925117$}

Molloy, G. J., Messerli-Bürgy, N., Hutton, G., Wikman, A., Perkins-Porras, L., \& Steptoe, A. (2014). Intentional and unintentional non-adherence to medications following an acute coronary syndrome: a longitudinal study. Journal of Psychosomatic Research, 76(5), 430-432. doi: 10.1016/j.jpsychores.2014.02.007

Moon, Z., Moss-Morris, R., Hunter, M. S., \& Hughes, L. D. (2017). More than just side-effects: The role of clinical and psychosocial factors in non-adherence to tamoxifen. British Journal of Health Psychology, 22(4), 998-1018. doi:

10.1111/bjhp.12274

Morisky, D. E., Green, L. W., \& Levine, D. M. (1986). Concurrent and predictive validity of a self-reported measure of medication adherence. Medical Care, 67-74.

Moskowitz, D. S., \& Young, S. N. (2006). Ecological momentary assessment: what it is and why it is a method of the future in clinical psychopharmacology. Journal of Psychiatry and Neuroscience, 31(1), 13. 
Mundt, J. C., Marks, I. M., Shear, M. K., \& Greist, J. M. (2002). The Work and Social Adjustment Scale: a simple measure of impairment in functioning. The British Journal of Psychiatry, 180(5), 461-464. doi: 10.1192/bjp.180.5.461

Munro, S., Lewin, S., Swart, T., \& Volmink, J. (2007). A review of health behaviour theories: how useful are these for developing interventions to promote long-term medication adherence for TB and HIV/AIDS? BMC Public Health, 7(1), 104. doi: 10.1186/14712458-7-104

Ortego, C., Huedo-Medina, T. B., Llorca, J., Sevilla, L., Santos, P., Rodríguez, E., . . Vejo, J. (2011). Adherence to Highly Active Antiretroviral Therapy (HAART): A Meta-Analysis. AIDS and Behavior, 15(7), 1381-1396. doi: 10.1007/s10461-011-9942-x

Rachlis, B. S., Mills, E. J., \& Cole, D. C. (2011). Livelihood security and adherence to antiretroviral therapy in low and middle income settings: a systematic review. PloS One, 6(5), e18948. doi: 10.1371/journal.pone.0018948

Raines, C., Radcliffe, O., \& Treisman, G. J. (2005). Neurologic and psychiatric complications of antiretroviral agents. Journal of the Association of Nurses in AIDS Care, 16(5), 3548. doi: 10.1016/j.jana.2005.07.004

Rich, A., Brandes, K., Mullan, B., \& Hagger, M. S. (2015). Theory of planned behavior and adherence in chronic illness: a meta-analysis. Journal of Behavioral Medicine, 38(4), 673-688. doi: 10.1007/s10865-015-9644-3

Salt, E., Hall, L., Peden, A., \& Horne, R. (2012). Psychometric properties of three medication adherence scales in patients with rheumatoid arthritis. Journal of Nursing Measurement, 20(1), 59. 
Scott, W., \& McCracken, L. M. (2015). Psychological flexibility, acceptance and commitment therapy, and chronic pain. Current Opinion in Psychology, 2, 91-96. doi: 10.1016/j.copsyc.2014.12.013

Simoni, J. M., Kurth, A. E., Pearson, C. R., Pantalone, D. W., Merrill, J. O., \& Frick, P. A. (2006). Self-report measures of antiretroviral therapy adherence: a review with recommendations for HIV research and clinical management. AIDS and Behavior, 10(3), 227-245. doi: doi: 10.1007/s10461-006-9078-6

Skinta, M. D., Lezama, M., Wells, G., \& Dilley, J. W. (2014). Acceptance and CompassionBased Group Therapy to Reduce HIV Stigma. Cognitive and Behavioral Practice.

Steinbrink, F., Evers, S., Buerke, B., Young, P., Arendt, G., Koutsilieri, E., . . . HIV/AIDS, G. C. N. (2013). Cognitive impairment in HIV infection is associated with MRI and CSF pattern of neurodegeneration. European Journal of Neurology, 20(3), 420-428. doi: 10.1111/ene.12006

Tommelein, E., Mehuys, E., Van Tongelen, I., Brusselle, G., \& Boussery, K. (2014). Accuracy of the Medication Adherence Report Scale (MARS-5) as a quantitative measure of adherence to inhalation medication in patients with COPD. Annals of Pharmacotherapy, 48(5), 589-595. doi: 10.1177/1060028014522982

UNAIDS. (2014). Global statistics.

http://www.unaids.org/en/resources/campaigns/HowAIDSchangedeverything/facts heet.

Uthman, O. A., Magidson, J. F., Safren, S. A., \& Nachega, J. B. (2014). Depression and adherence to antiretroviral therapy in low-, middle-and high-income countries: a systematic review and meta-analysis. Current HIV/AIDS Reports, 11(3), 291-307. doi: 10.1007/s11904-014-0220-1 
Veehof, M., Trompetter, H., BohImeijer, E. T., \& Schreurs, K. M. G. (2016). Acceptance-and mindfulness-based interventions for the treatment of chronic pain: a meta-analytic review. Cognitive Behaviour Therapy, 45(1), 5-31. doi:

$10.1080 / 16506073.2015 .1098724$

Vilardaga, R., Hayes, S. C., \& Schelin, L. (2007). Philosophical, theoretical and empirical foundations of Acceptance and Commitment Therapy. Anuario de Psicología The Universitat de Barcelona, 38(1), 117-128.

World Health Organisation (WHO) (2017). HIV/AIDS: Data and statistics [accessed online]. http://www.who.int/hiv/data/en/ 
Table 1 Participant characteristics according to MARS-5 cut-offs ( $N=275$ )

\begin{tabular}{|c|c|c|c|}
\hline & $\begin{array}{c}\text { Adherent } \\
\text { (according to MARS-5 } \\
\text { cut-off) } \\
(n=113,41.1 \%)\end{array}$ & $\begin{array}{c}\text { Nonadherent } \\
\text { (according to MARS-5 } \\
\text { cut-off) } \\
(n=162,58.9 \%)\end{array}$ & $p$ value \\
\hline Mean age (SD) & $47.79(12.93)$ & $48.29(11.66)$ & .74 \\
\hline Gender (\%) & & & .20 \\
\hline Cisgender man & $86(77.5)$ & 115 (70.1) & \\
\hline Cisgender woman & $24(21.6)$ & $45(27.4)$ & \\
\hline Transgender woman & 0 & $3(1.8)$ & \\
\hline Other & $1(0.9)$ & $1(0.6)$ & \\
\hline Country (\%) & & & .08 \\
\hline UK & $46(40.7)$ & $83(51.2)$ & \\
\hline Non-UK) & $66(58.4)$ & $78(48.1)$ & \\
\hline White ethnicity (\%) & $82(72.5)$ & $122(75.3)$ & .15 \\
\hline Employment status (\%) & & & .53 \\
\hline Full time & $48(42.4)$ & $75(46.2)$ & \\
\hline Part time & $10(8.4)$ & $23(14.1)$ & \\
\hline Education & $6(5.3)$ & $(2.4)$ & \\
\hline Homemaker & 0 & $1(0.6)$ & \\
\hline Retired & $14(12.3)$ & $19(11.7)$ & \\
\hline Unemployed & $32(28.3)$ & $38(23.4)$ & \\
\hline Other) & $(0.8)$ & $(0.6)$ & \\
\hline Relationship status (\%) & & & $.048^{*}$ \\
\hline Single & $45(39.8)$ & $85(52.4)$ & \\
\hline Married or civil partnership & $31(27.4)$ & $24(14.8)$ & \\
\hline
\end{tabular}


Separated or divorced

Cohabiting

Widowed

Other)

Sexual orientation (\%)

Gay

Bisexual

Straight

Other)

Mean disease duration (SD)

Depression PHQ-4 (\%)

Anxiety PHQ-4 (\%)

Mean Cognitive Complaints

$\mathrm{BC}-\mathrm{CCl}$ (SD)

Intentionally nonadherent

MARS-5 (\%)

Unintentionally nonadherent

MARS-5 (\%)

NA

152 (94)

NA items: screen 'yes/caseness' for values >3); MARS-5 (Medication Adherence Rating Scale five items: 'adherence' 25 and 'nonadherence' <25). 
Table 2: Summary of bivariate correlations (sample sizes range from $n=252$ to $n=275$ )

\begin{tabular}{|c|c|c|c|c|c|c|c|c|}
\hline & $\begin{array}{l}\text { MARS-5 } \\
\text { Unintent }\end{array}$ & WSAS & $\mathrm{BC}-\mathrm{CCl}$ & AAQ II & CAQ- 8 & SF-EQ & $\begin{array}{c}\text { PHQ-4 } \\
\text { dep }\end{array}$ & $\begin{array}{c}\text { PHQ-4 } \\
\text { anx }\end{array}$ \\
\hline $\begin{array}{l}\text { MARS-5 } \\
\text { Intent }\end{array}$ & NA & $.18^{* *}$ & $.25^{* *}$ & $.18^{* *}$ & $-.22^{* *}$ & -0.15 & $.22^{* *}$ & $.18^{* *}$ \\
\hline $\begin{array}{l}\text { MARS-5 } \\
\text { Unintent }\end{array}$ & & 0.031 & $.18^{* *}$ & 0.04 & $-.14^{*}$ & -0.09 & 0.06 & 0.07 \\
\hline WSAS & & & $.63^{* *}$ & $.49^{* *}$ & $-.42^{* *}$ & $-.34^{* *}$ & $.50^{* *}$ & $.44^{* *}$ \\
\hline $\mathrm{BC}-\mathrm{CCl}$ & & & & $.48^{* *}$ & $-.44^{* *}$ & $-.38^{* *}$ & $.47^{* *}$ & $.48^{* *}$ \\
\hline AAQ-II & & & & & $-.64^{* *}$ & $-.61^{* *}$ & $.70^{* *}$ & $.65^{* *}$ \\
\hline CAQ-8 & & & & & & $.63^{* *}$ & $-.57^{* *}$ & $-.56^{* *}$ \\
\hline SF-EQ & & & & & & & $-.55^{* *}$ & $-.59^{* *}$ \\
\hline PHQ-4 dep & & & & & & & & $.71^{* *}$ \\
\hline $\begin{array}{l}\text { Italics = point } \\
* \text { Correlation is } \\
\text { (British Columb } \\
\text { items), MARS- } \\
\text { (Medication Ad } \\
5 \text { unintent (Me } \\
\text { score), PHQ-4 } \\
\text { Questionnaire } \\
\text { items anxiety s } \\
\text { WSAS (Work an }\end{array}$ & $\begin{array}{l}\text { biserial Pea } \\
\text { gnificant }<.0 \\
\text { Cognitive C } \\
\text { (Medication } \\
\text { erence Ratin } \\
\text { ication Adhe } \\
\text { otal (Patien } \\
\text { ur items de } \\
\text { bscale), SF-E } \\
\text { Social Adjus }\end{array}$ & $\begin{array}{l}\text { son's cc } \\
\text { (2-tailec } \\
\text { mplaints } \\
\text { Adheren } \\
\text { Scale fi } \\
\text { ence Rat } \\
\text { Health } \\
\text { ression } \\
\text { (Shorte } \\
\text { nent Sca }\end{array}$ & $\begin{array}{l}\text { rrelation } \\
\text { ); AAQ-II } \\
\text { Inventor } \\
\text { ce Ratin } \\
\text { e items i } \\
\text { ing Scale } \\
\text { Question } \\
\text { ubscale) } \\
\text { led versi } \\
\text { le). }\end{array}$ & $\begin{array}{l}{ }^{* *} \text { Corr } \\
\text { Acceptan } \\
\text {; CAQ-8 } \\
\text { Scale fi } \\
\text { entional } \\
\text { ve items } \\
\text { ire four } \\
\text { HQ-4 ar } \\
\text { of the }\end{array}$ & $\begin{array}{l}\text { ation is } \\
\text { and Act } \\
\text { ommitte } \\
\text { items } t \\
\text { onadher } \\
\text { unintenti } \\
\text { items), } P \\
\text { (Patien } \\
\text { perience }\end{array}$ & $\begin{array}{l}\text { significa } \\
\text { on Ques } \\
\text { Action } \\
\text { tal scor } \\
\text { nce subs } \\
\text { nal non } \\
\text { tQ-4 de } \\
\text { Health } \\
\text { Questio }\end{array}$ & $\begin{array}{l}t<.01 \\
\text { onnaire } \\
\text { uestionn } \\
\text { ), MARS } \\
\text { cale scor } \\
\text { dherence } \\
\text {. (Patie } \\
\text { luestionr } \\
\text { naire to }\end{array}$ & $\begin{array}{l}\text {-tailed); } \\
\text {; BC-CCI } \\
\text { ire eight } \\
5 \text { Intent } \\
\text {, MARS- } \\
\text { subscale } \\
\text { Health } \\
\text { are four } \\
\text { ( score); }\end{array}$ \\
\hline
\end{tabular}


Table 3 Multiple binomial logistic regression to predict intentional nonadherence (MARS5)

\begin{tabular}{|c|c|c|c|c|}
\hline \multirow{2}{*}{$\begin{array}{l}\text { Step 1: Demographic and disease variables } \\
\chi^{2}(6)=37.66(p<.001)\end{array}$} & \multicolumn{2}{|c|}{$n=272$} & \multicolumn{2}{|c|}{$R^{2}=.192$} \\
\hline & & & & \\
\hline \multirow[t]{2}{*}{$-2 L L=266.03$} & & & & \\
\hline & $\boldsymbol{b}$ & Bca $95 \% \mathrm{Cl}$ & OR & OR $95 \% \mathrm{Cl}$ \\
\hline \multicolumn{5}{|l|}{ Relationship status ${ }^{1}$} \\
\hline Single vs. Married / Civil partnership & -.19 & $-1.07, .55$ & .81 & $.38,1.74$ \\
\hline Single vs. Separated or divorced & .12 & $-1.21,1.18$ & 1.13 & $.37,3.40$ \\
\hline Single vs. Cohabiting & $-2.20 *$ & $-20.65,-1.05^{*}$ & .11 & $.02, .49$ \\
\hline Single vs. Widowed & -.76 & $-20.76, .60$ & .46 & $.11,1.85$ \\
\hline Single vs. Other & -.72 & $-20.21, .43$ & .48 & $.10,2.36$ \\
\hline Cognitive Complaints (BC-CCI) & $.10^{*}$ & $.03, .19 *$ & 1.11 & $1.03,1.19$ \\
\hline Depression (PHQ-4) & .16 & $-.06, .43$ & 1.18 & $.93,1.49$ \\
\hline Anxiety (PHQ-4) & -.01 & $-.26, .23$ & .98 & $.78,1.23$ \\
\hline Step 2: Psychological flexibility processes & & & & $R^{2}=199$ \\
\hline \multicolumn{5}{|l|}{$\Delta \chi^{2}(2)=1.49(p=.47)$} \\
\hline \multicolumn{5}{|l|}{$-2 L L=264.53$} \\
\hline & $\boldsymbol{b}$ & Bca $95 \% \mathrm{Cl}$ & OR & OR $95 \% \mathrm{Cl}$ \\
\hline Psychological inflexibility (AAQ-II) & -.01 & $-.07, .04$ & .98 & $.933,1.03$ \\
\hline Committed action (CAQ-8) & -.02 & $-.08, .02$ & .97 & $.931,1.01$ \\
\hline \multicolumn{5}{|c|}{$\begin{array}{l}\text { Adherent }=0 \text {, Nonadherent }=1 ;{ }^{1} \text { Single reference group }=0 ; \chi^{2} \text { Chi-squared goodness of fit; } \Delta \chi^{2} \text { (Chi-squared } \\
\text { goodness of fit); } b=\text { beta value; Bca } 95 \% \text { bootstrapped } \mathrm{Cl} \text { (beta value } 95 \% \text { confidence intervals with } 1000 \\
\text { samples); *beta is significant }<.05 \text { ( } 2 \text {-tailed); OR (standardized odds ratio); OR } 95 \% \mathrm{Cl} \text { (standardized odds } \\
\text { ratio } 95 \% \text { confidence intervals); -2LL(-2 Log Likelihood statistic); } R^{2} \text { (Nagelkerke } R^{2} / \text { pseudo } \mathrm{R}^{2} \text { ); AAQ-II } \\
\text { (Acceptance and Action Questionnaire II); CAQ- } 8 \text { (Committed Action Questionnaire eight items) BC-CCI } \\
\text { (British Columbia Cognitive Complaints Inventory); PHQ-4 (Patient Health Questionnaire four items). }\end{array}$} \\
\hline
\end{tabular}


Table 4 Multiple binomial logistic regression to predict unintentional nonadherence (MARS-5)

\begin{tabular}{|c|c|c|c|c|}
\hline \multicolumn{2}{|l|}{ Step 1: Demographic and disease variables } & & \multicolumn{2}{|c|}{$R^{2}=.119$} \\
\hline \multicolumn{5}{|l|}{$\chi^{2}(7)=25.39(p<.001)$} \\
\hline \multicolumn{5}{|l|}{$-2 L L=350.22$} \\
\hline & $\boldsymbol{b}$ & Bca $95 \% \mathrm{Cl}$ & OR & OR 95\% Cl \\
\hline \multicolumn{5}{|l|}{ Relationship status ${ }^{1}$} \\
\hline Single vs. Married / Civil partnership & $-.79 *$ & $-1.50,-.16^{*}$ & .45 & $.23, .86$ \\
\hline Single vs. Separated or divorced & -.26 & $-1.35, .97$ & .76 & $.27,2.18$ \\
\hline Single vs. Cohabiting & -.02 & $-.82, .82$ & .97 & $.46,2.07$ \\
\hline Single vs. Widowed & $-1.78^{*}$ & $-3.71,-.55^{*}$ & .16 & .04 .598 \\
\hline Single vs. Other & -.04 & $-1.33,1.39$ & .95 & $.31,2.95$ \\
\hline Years since diagnosis & $.02 *$ & $<.01, .05^{*}$ & 1.02 & $1.00,1.04$ \\
\hline Cognitive Complaints (BC-CCl) & $.07^{*}$ & $.02, .14^{*}$ & 1.08 & $1.02,1.14$ \\
\hline Step 2: Psychological flexibility processes & & & & $=.122$ \\
\hline \multicolumn{5}{|l|}{$\Delta \chi^{2}(1)=.69(p=.40)$} \\
\hline \multicolumn{5}{|l|}{$-2 \mathrm{LL}=349.53$} \\
\hline & $b$ & Bca $95 \% \mathrm{Cl}$ & OR & OR $95 \% \mathrm{Cl}$ \\
\hline Committed action (CAQ-8) & -.01 & $-.04, .02$ & .98 & $.95,1.01$ \\
\hline \multicolumn{5}{|c|}{$\begin{array}{l}\text { Adherent }=0 \text {, Nonadherent }=1 ;{ }^{1} \text { Single reference group }=0 ; \chi^{2} \text { Chi-squared goodness of fit; } \Delta \chi^{2} \text { (Chi-squared } \\
\text { goodness of fit); } b=\text { beta value; Bca } 95 \% \text { bootstrapped } \mathrm{Cl} \text { (beta value } 95 \% \text { confidence intervals with } 1000 \\
\text { samples); *beta is significant <.05 (2-tailed); OR (standardized odds ratio); OR } 95 \% \mathrm{Cl} \text { (standardized odds } \\
\text { ratio } 95 \% \text { confidence intervals); -2LL(-2 Log Likelihood statistic); } R^{2} \text { (Nagelkerke } R^{2} / \text { pseudo } \mathrm{R}^{2} \text { ); AAQ-II } \\
\text { (Acceptance and Action Questionnaire II); CAQ-8 (Committed Action Questionnaire eight items) BC-CCI } \\
\text { (British Columbia Cognitive Complaints Inventory); PHQ-4 (Patient Health Questionnaire four items). }\end{array}$} \\
\hline
\end{tabular}

